\title{
Bone-anchored annular closure following lumbar discectomy reduces risk of complications and reoperations within $\mathbf{9 0}$ days of discharge [Corrigendum]
}

Klassen PD, Bernstein DT, Köhler HP, et al. Bone-anchored annular closure following lumbar discectomy reduces risk of complications and reoperations within 90 days of discharge. Journal of Pain Research. 2017;10:2047-2055.

The authors advise that the word "Hypesthesia" in Table 2 on page 2051 should read "Nerve root injury resulting in hypesthesia"

Table 2 has been edited accordingly and is provided below. Aside from this clarification, all data in the original paper remain correct as reported.

Table 2 Listing of device- or procedure-related serious adverse events through 90 days following hospital discharge

\begin{tabular}{lll}
\hline Characteristic & $\begin{array}{l}\text { Annular } \\
\text { closure }(\mathbf{N}=\mathbf{2 7 2})\end{array}$ & $\begin{array}{l}\text { Control } \\
\mathbf{( N = 2 7 8 )}\end{array}$ \\
\hline Patients reporting at least one SAE & $12(4.4 \%)^{*}$ & $26(9.4 \%)^{* *}$ \\
Index-level herniation & 6 & 19 \\
Wound complication & 2 & 6 \\
Epidural hematoma & 0 & 2 \\
Anchor/mesh dislocation & 2 & 0 \\
Back/leg pain & 2 & 0 \\
Coronary heart disease & 0 & 1 \\
Dural tear & 0 & 1 \\
Nerve root injury resulting in & $\mathrm{I}$ & 0 \\
hypesthesia & & \\
\hline
\end{tabular}

Notes: $* 13$ events in 12 patients, $* 22$ events in 26 patients.

Abbreviation: SAE, serious adverse event.

\section{Publish your work in this journal}

The Journal of Pain Research is an international, peer reviewed, open access, online journal that welcomes laboratory and clinical findings in the fields of pain research and the prevention and management of pain. Original research, reviews, symposium reports, hypothesis formation and commentaries are all considered for publication.

\section{Dovepress}

The manuscript management system is completely online and includes a very quick and fair peer-review system, which is all easy to use. Visit http://www.dovepress.com/testimonials.php to read real quotes from published authors. 